УДК 355.424 .4

Дмитро Вікторович Резнік (канд. військ. наук.)

Михайло Антонович Левченко (канд. військ. наук, доцент)

Олег Андрійович Заболотний (канд. військ. наук, доцент)

Василь Семенович Мельниченко (канд. військ. наук, доцент)

Національний університет оборони Украӥни імені Івана Черняховського, Київ, Украӥна

\title{
МЕТОДИКА ФОРМУВАННЯ ТАБЛИЦІ ВЗАЄМОДІї
}

Пошук нових підходів та розробка на їх основі інструментів щзодо підтримки прийняття рішення командуючого (командира) на організацію взаємодї сил $і$ засобів в ході ведення сучасних бойових дій, які характеризуються швидкоплинною зміною обстановки, останнім часом стало предметом інтенсивних наукових досліджень. Одним із перспективних напрямків таких досліджень є розроблення спеціальних автоматизованих систем, щчо використовуються для формування таблиці взаємодї сил $i$ засобів під час сумісного виконання ними оперативних (бойових) завдань. Дослідження у галузі розробки таких систем призвели до появи (висунення) нових вимог формування таблиці взаємодії. По-перше, таблиця має враховувати не тільки достовірні дані о поточній оперативно-тактичній обстановці, а й дані щодо ї̈ зміни в режимі часу, наближеному до реального. По-друге, автоматизована система в проиесі формування таблиці взаємодї повинна мати та використовувати базу знань щзодо ї організаџї, яка формується та постійно оновлюється на підставі попереднього досвіду ведення операцій (бойових дій). У статті описується один із підходів автоматизованого формування таблиці взаємодії зенітних ракетних військ з винищувальною авіацією, який заснований на застосуванні метода декомпозиції багатокритеріальної задачі.

Ключові слова: таблиця взаємодї;; декомпозиція; автоматизація формування; багатокритеріальна задача, протиповітряна оборона.

\section{Вступ}

Ефективність протиповітряної оборони багато в чому визначається ступенем реалізації плану бойових дій на всіх рівнях: від окремої військової частини (підрозділу) зенітних ракетних військ (ЗРВ) або винищувальної авіації (ВА) до угруповання протиповітряної оборони (ППО) в цілому [1].

Однією $з$ найважливіших складових підготовки бойових дій є організація взаємодії між силами та засобами, які спільно виконують поставлені завдання, а інструментом узгодження дій окремих елементів системи ППО є таблиця взаємодії (ТВ), яка призначена для координації дій сил та засобів ЗРB i BA [1].

Постановка проблеми. Отже, основним документом організації взаємодії військ є таблиця взаємодії, структура якої відноситься до структури розкладів, в яких також необхідно впорядковувати або, іншими словами, визначати послідовність виконання сукупності дій (робіт), або використання будь-яких сил і засобів. Рішення завдань упорядкування, які виникають там, де існує можливість вибору тієї чи іншої послідовності виконання дій (при розподілі робіт на виробництві, складанні розкладу приземлення літаків, складанні розкладу руху поїздів, обслуговуванні клієнтів тощо), здійснюється за допомогою теорії розкладів [5-9].

3 вищесказаного випливає, що формування таблиці взаємодії ЗРВ з ВА, яка враховує загальні завдання та умови їх виконання $\epsilon$ актуальною i важливою науково-практичною задачею, вирішення якої повинно дозволити:

- $\quad$ з точки зору розробки математичної моделі: $\checkmark$ знизити обчислювальні труднощі і спростити рішення складної багатокритеріальної задачі; обгрунтувати i максимально формалізувати критерії на кожному етапі реалізації методики формування ТВ;

$\checkmark$ удосконалити методику узгодження часткових критеріїв кожного рівня ієрархії 3 глобальним критерієм оптимальності підвищенням ефективності організації взаємодії ЗРВ з ВА;

$\checkmark$ врахувати необхідність наукового обгрунтування “ручного” коригування ТВ 3 урахуванням знань, накопичених в результаті формування ТВ вручну;

- 3 точки зору розробки алгоритму автоматизації:

$\checkmark$ знизити трудомісткість виконання ручних операцій щодо формування ТВ;
$\checkmark$ впровадити ефективну систему контролю помилок і логічної невідповідності в отриманій ТВ;

$\checkmark$ максимально врахувати основну мету бойових дій та особливості застосування ЗРВ та ВА в конкретних умовах ведення операції (бойових дій). 
Аналіз остатніх досліджень і публікацій. В останній час ведуться дослідження в області розробки методик автоматизації процесу формування розкладів. Більшість 3 них спрямовано на розроблення алгоритмів формування оптимального розкладу на основі одного або декількох критеріїв [2] 3 урахуванням специфічних вимог до конкретного розкладу і його рівномірності за рівнем складності виконуваних завдань [6,7]. Також, поширеними $\epsilon$ дослідницькі роботи, в яких формування розкладу здійснюється на підставі теорії графів [5], генетичних [7], а також евристичних алгоритмів [9].

Однак, комп'ютерні програми автоматичного формування розкладів, які базуються на існуючих моделях, орієнтовані на умови конкретного виробництва або мають зайву універсальність реалізації загальних функцій із формування розкладів $[6,7]$, високу ринкову вартість і не можуть бути пристосованими до вирішення завдання організації взаємодії військ під час ведення операції (бойових дій).

Метою статті є удосконалення методики вирішення багатокритеріальної задачі автоматизованого формування ТВ зенітних ракетних військ (ЗРВ) з винищувальною авіацією (ВА).

\section{Виклад основного матеріалу дослідження}

Взаємодія ЗРВ 3 ВА $є$ складним процесом координації порядку знищення засобів повітряного нападу (ЗПН) за рахунок часткової зміни типового складу сил і засобів ЗРВ та ВА та їх порядку застосування.

Засобом управління силами та засобами ЗРВ i ВА в ході відбиття удару ЗПН противника i одночасно основою вибору раціонального способу їх взаємодії $є$ таблиця взаємодії, що має динамічну структуру, яка відображає включення або виключення вогневих одиниць 3 бойових дій на всьому інтервалі часу відбиття удару повітряного противника. Завдання ii побудови та оптимізації належить до класу задач складання розкладів.
При цьому вибір раціональних способів взаємодії ЗРВ 3 ВА $\epsilon$ достатньо складним завданням, що обумовлено перехресністю схем знищення повітряного противника i багатоваріантністю способів виконання завдання силами та засобами ЗРВ та ВА.

Крім того, існує певна проблема під час здійснення взаємодії в ході ведення бойових дій, яка полягає в необхідності оперативного прийняття рішень 3 питань корегування планової таблиці взаємодії в режимі реального часу у зв'язку з невідповідністю поточної обстановки тій, яка прогнозувалася під час первинного формування ТВ.

Для вирішення цієї проблеми пропонується така методика формування ТВ ЗРВ з ВА.

Першим кроком цієї методики $є$ формування ієрархічної структури підзадач багатокритеріальної задачі формування ТВ шляхом виконання декомпозиції загальної задачі за такими ознаками: за об'єктами автоматизації; за критеріями оптимізації та по етапах ії реалізації $[6,7]$.

Проведення процедури декомпозиції загальної задачі на множині локальних об’єктів автоматизації процесу формування ТВ дозволило виділити такі ïï структурні елементи (рис. 1):

листи робочої таблиці $\mathrm{O}_{1}$, на яких розміщується як вихідна інформація для формування ТВ $\left(\mathrm{O}_{11}, \mathrm{O}_{12}\right)$, так i заплановані результати іiі реалізації фактична бойова напруженість вогневих засобів $\left(\mathrm{O}_{13}\right)$, а також показники якості ТВ ( $\left.\mathrm{O}_{14}\right)$, що сформована;

елемент користувача $\mathrm{O}_{2}$, який реалізує основні технологічні операції по формуванню та перевірки ТВ $\left(\mathrm{O}_{21}, \mathrm{O}_{22}\right)$.

Аналіз критеріїв багатокритеріальної задачі автоматизації процедури формування ТВ дозволяє виділити дві групи локальних критеріїв (рис. 2):

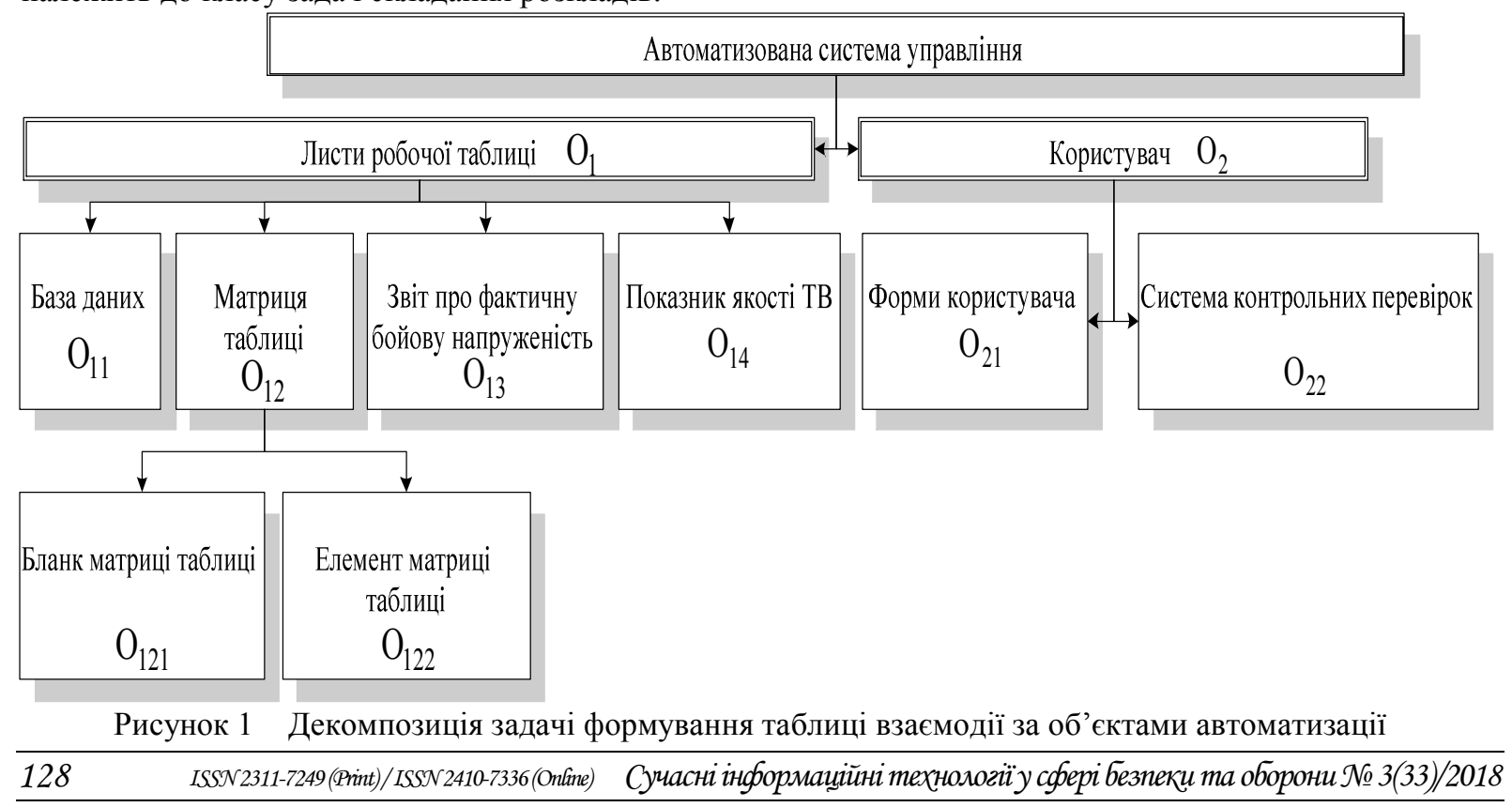




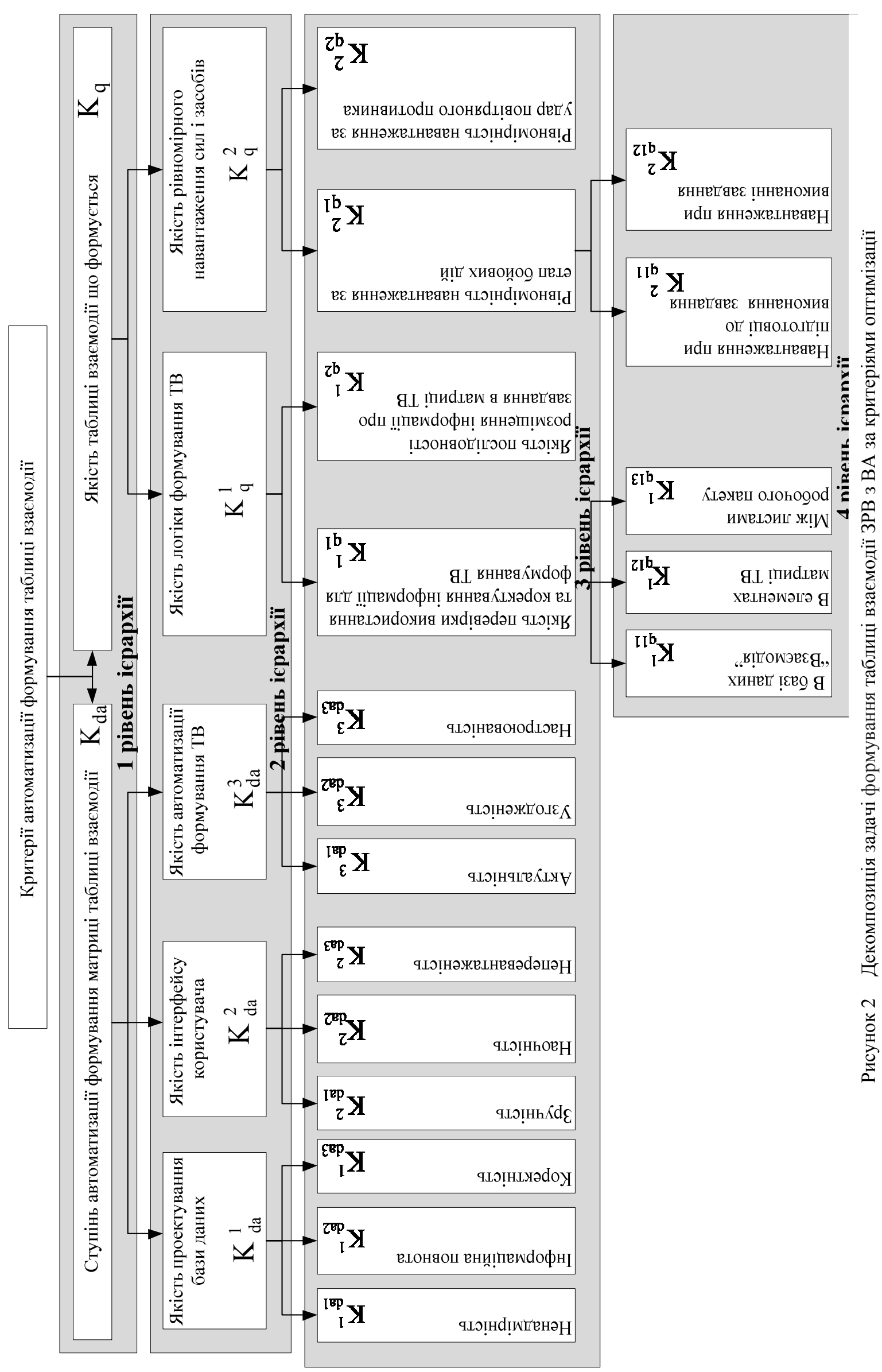


ступінь автоматизації процедури формування матриці $\mathrm{TB} \mathrm{K}_{\mathrm{da}}$;

якість ТВ, що формується $\mathrm{K}_{\mathrm{q}}$.

Оптимізація рівня автоматизації за показником $\mathrm{K}_{\mathrm{da}}$ виконується 3 урахуванням компонентів якості $\mathrm{K}_{\mathrm{da}}^{\mathrm{i}}$, де $\mathrm{i}$ індекс локального критерію 2го рівня ієрархії ( $\mathrm{i}=1, \mathrm{I})$ :

якість проектування бази даних $\mathrm{K}_{\mathrm{da}}^{1}$;

якість інтерфейсу користувача $\mathrm{K}_{\mathrm{da}}^{2}$;

якість автоматизації формування ТВ $\mathrm{K}_{\mathrm{da}}^{3}$.

Кожен 3 визначених компонентів якості ступеня автоматизації процедури формування ТВ, в свою чергу, піддається декомпозиції на групи локальних критеріїв 3-го рівня iєрархії $\mathrm{K}_{\mathrm{da}}^{\mathrm{i}} \mathrm{j}$, де $\mathrm{j}$

індекс локального критерію 3-го рівня ієрархії $(\mathrm{j}=1, \mathrm{~J})$.

Оптимізація якості формованої ТВ за показником $\mathrm{K}_{\mathrm{q}}$ передбачає досягнення екстремумів наступних локальних критеріїв $\mathrm{K}_{\mathrm{q}}^{\mathrm{i}}$ :

“логічна" якість $\mathrm{K}_{\mathrm{q}}^{1}$;

рівномірність навантаження сил і засобів $\mathrm{K}_{\mathrm{q}}^{2}$.

Кожен 3 компонентів якості ТВ, що сформовано, в свою чергу, піддається декомпозиції на групи локальних критеріїв:

3-го рівня ієрархії $\mathrm{K}_{\mathrm{q} \mathrm{j}}^{\mathrm{i}}$;

4-го рівня ієрархії $\mathrm{K}_{\text {qjm }}^{\mathrm{i}}$, де $\mathrm{m}$ індекс локального критерію 4-го рівня ієрархії $(\mathrm{m}=1, \mathrm{M})$.

Етапи реалізації задачі автоматизації формування ТВ (рис. 3) є результатами декомпозиції за третьою ознакою.
Множину можливих задач $\mathrm{E}$ автоматизації процесу формування ТВ пропонується задавати символьною формулою, побудованою за принципом: умовне позначення структурної складової утворюється послідовним записом зліва направо умовних позначень об'єктів автоматизації і множини локальних критеріїв.

Аналіз множини локальних задач, отриманих в результаті синтезу результатів трьох видів декомпозиції (рис. 1, 2, 3), дозволив виділити наступний склад елементів ієрархічної структури процесу автоматизації формування ТВ, формалізація яких представлена в наступному порядку:

задача $\mathrm{E}_{11}$ проектування та формування бази даних ТВ за напрямками виконуваних задач:

$$
\mathrm{E}_{11}=\mathrm{O}_{11}\left\{\mathrm{~K}_{\mathrm{da}}^{1}\right\}
$$

задача $\mathrm{E}_{12}$ формування бланка сітки таблиці:

$$
\mathrm{E}_{12}=\mathrm{O}_{121}\left\{\mathrm{~K}_{\mathrm{da}}^{2} \mathrm{~K}_{\mathrm{da} 2}^{1}\right\}
$$

задача $\mathrm{E}_{21}$ формування форми користувача, що надає вихідну інформацію для заповнення ТВ:

$$
\left.\left.\mathrm{E}_{21}=\left\{\mathrm{O}_{21} \mathrm{O}_{122}\right)\right\} \mathrm{K}_{\mathrm{da}}^{2} \mathrm{~K}_{\mathrm{da} 2}^{3}\left\{\mathrm{~K}_{\mathrm{da} 2}^{1} \mathrm{~K}_{\mathrm{da} 3}^{1}\right)\left(\mathrm{K}_{\mathrm{q} 11}^{1} \mathrm{~K}_{\mathrm{q} 12}^{1}\right\}\right\}
$$

задача $\mathrm{E}_{22}$ заповнення матриці бланка ТВ, які відповідають за інформацію про стан і положення вогневих одиниць:

$$
\left.\mathrm{E}_{22}=\left\{\mathrm{O}_{21} \mathrm{O}_{22} \mathrm{O}_{122}\right\}\right\} \mathrm{K}_{\mathrm{da}}^{2} \mathrm{~K}_{\mathrm{da} 3}^{3}\left\{\mathrm{~K}_{\mathrm{da} 2}^{1} \mathrm{~K}_{\mathrm{da} 3}^{1} \mathrm{~K}_{\mathrm{q} 1}^{1} \mathrm{~K}_{\mathrm{q} 2}^{1}\right\}
$$

задача $\mathrm{E}_{31}$ формування звітної інформації про завантаження вогневих одиниць і розподіл всіх задач:

$$
\mathrm{E}_{31}=\mathrm{O}_{13}\left\{\mathrm{~K}_{\mathrm{da} 2}^{1} \mathrm{~K}_{\mathrm{da} 3}^{1}\left\{\mathrm{~K}_{\mathrm{da} 1}^{3} \mathrm{~K}_{\mathrm{da} 3}^{3}\right\}\right\}
$$

задача $\mathrm{E}_{32}$ розрахунку агрегованих показників якості таблиці взаємодії, що сформована:

$$
\mathrm{E}_{32}=\mathrm{O}_{14}\left\{\mathrm{~K}_{\mathrm{q}}^{2}\right\}
$$

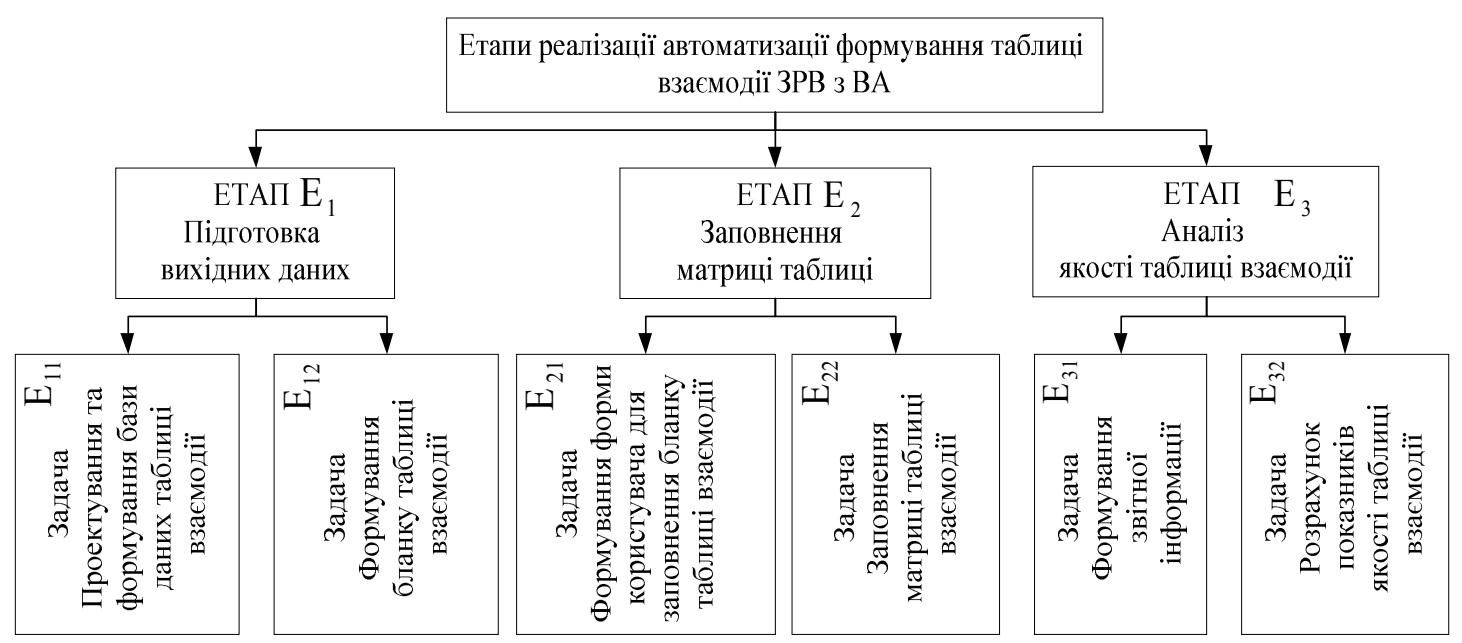

Рисунок 3 Декомпозиція задачі формування таблиці взаємодії ЗРВ з ВА за етапами ії реалізації 
Реалізація другого етапу декомпозиції багатовимірної задачі автоматизації формування ТВ передбачає організацію спільного рішення системи отриманих локальних задач, яка включає вибір:

методу локального критерію i розробку алгоритму вирішення кожної задачі;

координацію процесу обміну інформацією між задачами;

корекцію рішення задачі відповідно до загального критерію оптимальності.

У загальному вигляді $\mathrm{p}$ ю задачу системи можна представити наступним чином:

$$
\mathrm{f}_{\mathrm{p}}\left(\mathrm{X}_{\mathrm{p}}, \mathrm{Y}_{\mathrm{p}}, \mathrm{Z}_{\mathrm{p}}\right) \rightarrow \text { extr }
$$

де $\mathrm{Z}_{\mathrm{p}}$ локальний критерій оптимальності $\mathrm{p}-і$ задачі формування ТВ;

$\mathrm{X}_{\mathrm{p}}$ вхідна інформація $\mathrm{p}-\mathrm{i} \quad$ задачі формування ТВ;

$\mathrm{Y}_{\mathrm{p}}$ вихідна інформація $\mathrm{p}-\mathrm{i}$ задачі автоматизації процесу формування ТВ.

Схема інформаційної взаємодії та координації процесу вирішення завдань отриманої декомпозиційної структури представлена на рис. 4. Розглянемо запропоновану методику автоматизованого формування ТВ.

Методика складається з 3-х етапів і 6-и завдань.

Реалізація етапу ( $\mathrm{E}_{1}$ підготовки вихідної інформації для формування ТВ) передбачає послідовне вирішення двох задач $\mathrm{E}_{11}$ i $\mathrm{E}_{12}$. Перша задача $\left(\mathrm{E}_{11}\right)$ формує та заповнює бази даних вихідною інформацією для формування бланку таблиці взаємодії. Математична формалізація даної задачі (1) може бути записана в наступному вигляді:

$$
\mathrm{f}_{11}\left(\mathrm{X}_{11}, \mathrm{Y}_{11}, \mathrm{Z}_{11}\right) \rightarrow \operatorname{extr}
$$

де $\mathrm{X}_{11}=\left\{\mathrm{X}_{111}, \mathrm{X}_{112}, \mathrm{Y}_{22}\right\}$ множина елементів вектора вхідної інформації задачі $\mathrm{E}_{11}$;

$$
\mathrm{Y}_{11}=\left\{\mathrm{Y}_{111}, \mathrm{Y}_{112}\right\} \quad \text { множина елементів }
$$
вектора вихідної інформації задачі $\mathrm{E}_{11}$;

$Z_{11}$ критерій оптимальності задачі $\mathrm{E}_{11}$.

Згідно синтезу результатів декомпозиції на першому етапі задачі автоматизації формування ТВ критерій оптимальності задачі $\epsilon$ комплексним (табл. 1) i полягає в максимізації якості проектування бази даних взаємодії ЗРВ з ВА, а точніше суми його зважених складових: не надмірності $\left(\mathrm{K}_{\mathrm{da1}}^{1}\right)$, інформаційної повноти $\left(\mathrm{K}_{\mathrm{da} 2}^{1}\right)$, коректності $\left(\mathrm{K}_{\mathrm{da} 3}^{1}\right)$ з урахуванням вагових коефіцієнтів значущості відповідних показників $\mathrm{w}_{1}, \mathrm{w}_{2}, \mathrm{w}_{3}$.

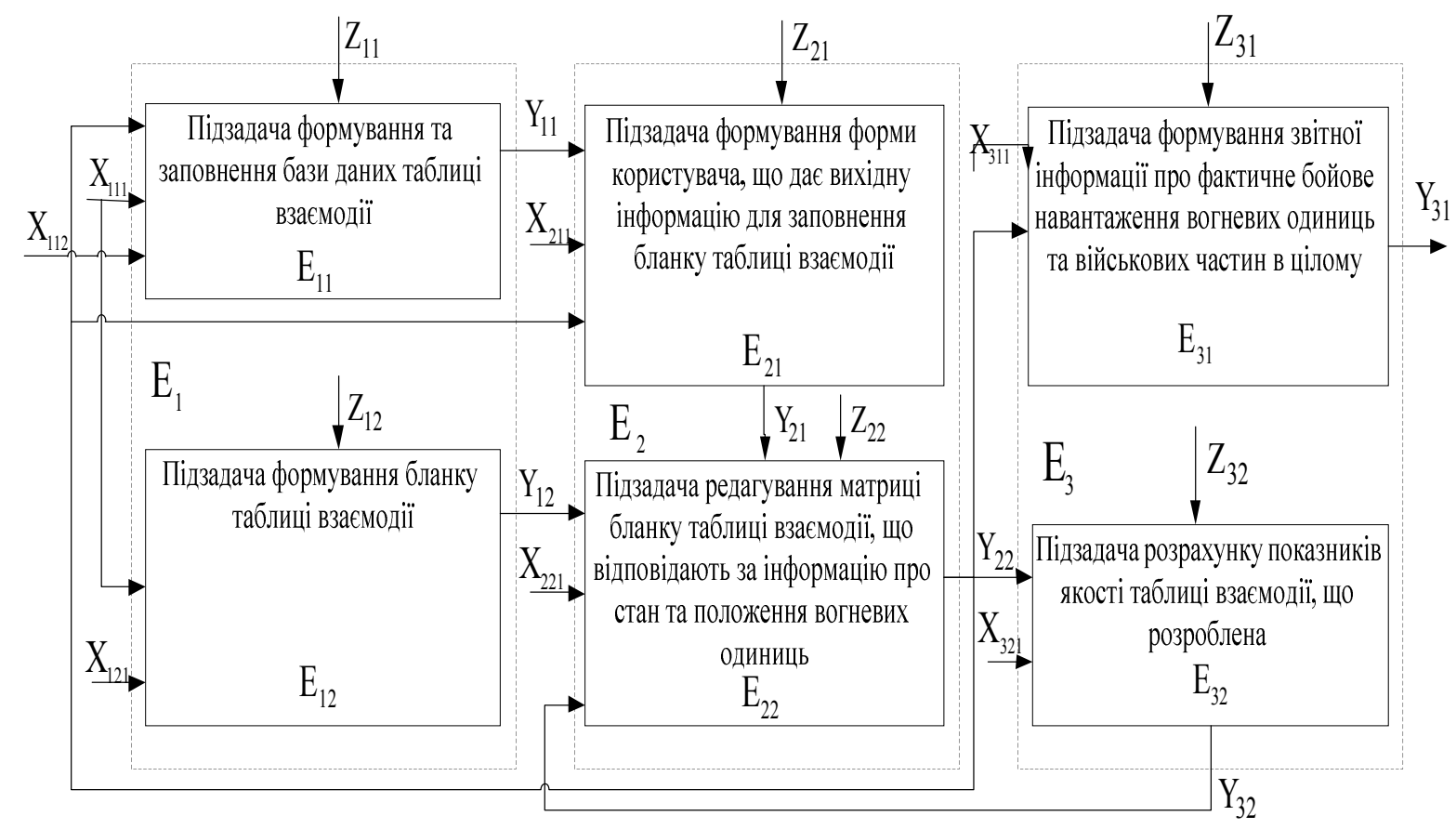

Рисунок 4 Методика формування таблиці взаємодії ЗРВ з ВА

Параметри задачі формування i заповнення вихідної інформації для формування бази даних представлені в табл. 1.

Структура таблиці "План застосування по бойових можливостях" ( $\left.\mathrm{Y}_{111}\right)$ представлена наступними полями: повна назва роду військ, назва груп вогневих одиниць, кількість часового ресурсу, відведеного на бойові дії, кількість ракет і боєприпасів, відведених на бойові дії тощо, формується на основі нормативної документації штабів по кожному роду військ $\left(\mathrm{X}_{111}\right)$.

Структура таблиці "Бойова напруженість по вогневим одиницям" ( $\mathrm{Y}_{112}$ ) складається $з$ двох груп: 
перша поля заповнюються первинною інформацією $\left(\mathrm{X}_{112}\right)$ для подальшого коригування;

друга поля будуть коригуватися за результатами рішення підзадачі $\mathrm{E}_{22}$ редагування компонентів сітки ТВ ( $\left.\mathrm{Y}_{22}\right)$.

Другою задачею етапу підготовки вихідної інформації ( $\left.\mathrm{E}_{1}\right) \epsilon$ формування бланка ТВ ( $\left.\mathrm{E}_{12}\right)$.

Математична формалізація даної задачі може бути записана в наступному вигляді:

$$
\mathrm{f}_{12}\left(\mathrm{X}_{12}, \mathrm{Y}_{12}, \mathrm{Z}_{12}\right) \rightarrow \text { extr }
$$

де $\mathrm{X}_{12}=\left\{\mathrm{X}_{111}, \mathrm{Y}_{22}\right\}$ множина елементів вектора вхідної інформації задачі $\mathrm{E}_{12} ; \mathrm{Y}_{12}$ вихідна інформація задачі $\mathrm{E}_{12}$;

$\mathrm{Z}_{12}$ критерій оптимальності задачі $\mathrm{E}_{12}$, який реалізує спосіб формування ТВ, що перебуває в максимізації суми зважених складових показника якості призначеного для користувача інтерфейсу формування бланка сітки ТВ (2), a саме ii зручність $\left(\mathrm{K}_{\mathrm{da} 1}^{2}\right)$, наочність $\left(\mathrm{K}_{\mathrm{da} 2}^{2}\right)$, не перевантаженість $\left(\mathrm{K}_{\mathrm{da3}}^{2}\right) \quad 3 \quad$ ваговими коефіцієнтами значущості $\mathrm{w}_{4}, \mathrm{w}_{5}, \mathrm{w}_{6}$ та інформаційна повнота ( $\mathrm{K}_{\mathrm{da} 2}^{1}$ ) (табл. 2).

Таблиця 1 Параметри завдання формування і заповнення бази даних ( $\left.\mathrm{E}_{11}\right)$

\begin{tabular}{|c|c|c|c|c|c|}
\hline \multicolumn{3}{|c|}{ Вхідна інформація $\mathrm{X}_{11}$} & \multirow{2}{*}{ Локальний критерій оптимальності $Z_{11}$} & \multicolumn{2}{|c|}{$\begin{array}{c}\text { Вихідна } \\
\text { інформація } \mathrm{Y}_{11}\end{array}$} \\
\hline $\mathrm{X}_{111}$ & $\mathrm{X}_{112}$ & $\mathrm{Y}_{22}$ & & $\mathrm{Y}_{111}$ & $\mathrm{Y}_{112}$ \\
\hline 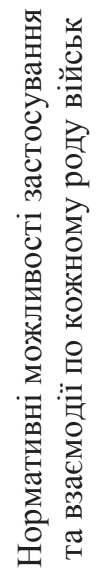 & 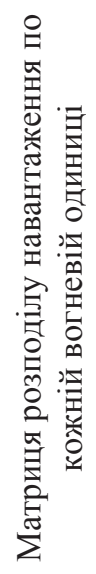 & 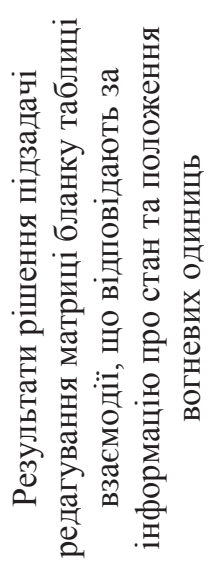 & $\mathrm{Z}_{11}=\mathrm{w}_{1} \mathrm{~K}_{\mathrm{da} 1}^{1}+\mathrm{w}_{2} \mathrm{~K}_{\mathrm{da} 2}^{1}+\mathrm{w}_{3} \mathrm{~K}_{\mathrm{da} 3}^{1} \rightarrow \max$ & 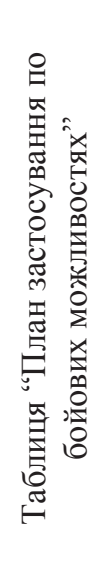 & 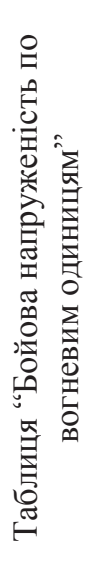 \\
\hline
\end{tabular}

Реалізація етапу 2 заповнення матриці ТВ ( $\left.\mathrm{E}_{2}\right)$ передбачає послідовне вирішення двох задач $\mathrm{E}_{21}$ i $\mathrm{E}_{22}$ (рис. 4).

Метою реалізації задачі формування форми користувача для заповнення бланка ТВ ( $\left.\mathrm{E}_{21}\right) \epsilon$ :

1. Надання користувачу повного обсягу інформації для заповнення бланка ТВ на поточному аркуші робочої книги і розташування іiі на екрані в наочному i зручному для використання вигляді.

2. Розробка i реалізація ефективних елементів інтерфейсу користувача для виконання переліку технологічних операцій, необхідних для формування TB в усіх напрямках застосування, а саме:

перегляд загального плану застосування; виділення рядка бойового навантаження, обраної для розміщення або редагування в сітці ТВ;

перегляд бойового навантаження за обраним родом військ, яке фактично розміщене в сітці ТВ;

перегляд бойового навантаження за обраним родом військ, яке потрібно розмістити в ТВ.

Математична формалізація даної задачі (3) може бути записана в наступному вигляді:

$$
\mathrm{f}_{21}\left(\mathrm{X}_{21}, \mathrm{Y}_{21}, \mathrm{Z}_{21}\right) \rightarrow \operatorname{extr}
$$
де $\mathrm{X}_{21}=\left\{\mathrm{X}_{211}, \mathrm{Y}_{11}, \mathrm{Y}_{22}\right\} \quad$ множина елементів вектора вхідної інформації задачі $\mathrm{E}_{21}$;

$$
\mathrm{Y}_{21}=\left\{\mathrm{Y}_{211}, \mathrm{Y}_{212}, \mathrm{Y}_{213}\right\}
$$

множина елементів вектора вихідної інформації задачі $\mathrm{E}_{21}$;

$Z_{21}$ комплексний критерій оптимальності задачі $\mathrm{E}_{21}$, який реалізує формування $\mathrm{TB}$, що перебуває в максимізації:

суми зважених складових показників коректності $Z_{\text {cor21 }}$ i узгодженості $Z_{\text {uzg21 }}$ матриці ТВ $(11,12)$;

суми зважених складових показника якості реалізації технологічних операцій із формування ТВ, а саме їх: інформаційної повноти $\mathrm{K}_{\mathrm{da} 2}^{1}$; якості призначеного для користувача інтерфейсу 3 точки зору використання, обробки та візуального відображення вихідної і поточної інформації бази даних $\mathrm{K}_{\mathrm{da}}^{2}$ (табл. 2). 
Таблиця 2 Параметри задачі формування бланка ТВ ( $\left.\mathrm{E}_{12}\right)$

\begin{tabular}{|c|c|c|}
\hline Вхідна інформація $\mathrm{X}_{111}$ & Локальний критерій оптимальності $Z_{12}$ & Вихідна інформація $\mathrm{Y}_{12}$ \\
\hline 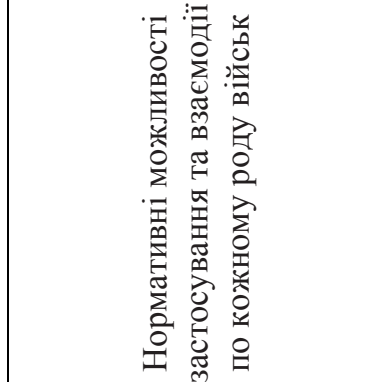 & $\mathrm{Z}_{12}=\mathrm{w}_{2} \mathrm{~K}_{\mathrm{da} 2}^{1}+\mathrm{w}_{4} \mathrm{~K}_{\mathrm{da} 1}^{2}+\mathrm{w}_{5} \mathrm{~K}_{\mathrm{da} 2}^{2}+\mathrm{w}_{6} \mathrm{~K}_{\mathrm{da} 3}^{2} \rightarrow \max$ & 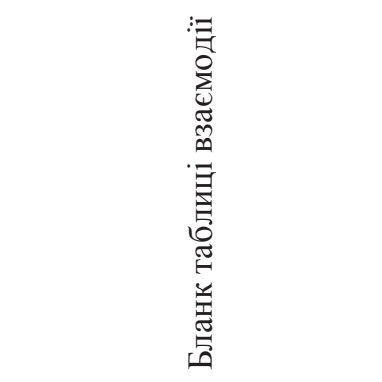 \\
\hline
\end{tabular}

Таблиця 3 Параметри задачі формування форми користувача ( $\left.\mathrm{E}_{21}\right)$

\begin{tabular}{|c|c|c|c|c|c|c|c|}
\hline \multicolumn{4}{|c|}{ Вхідна інформація $\mathrm{X}_{21}$} & \multirow{2}{*}{$\begin{array}{l}\text { Локальний критерій оптимальності } \\
\qquad Z_{21}\end{array}$} & \multicolumn{3}{|c|}{$\begin{array}{c}\text { Вихідна інформація } \\
\mathrm{Y}_{21}\end{array}$} \\
\hline$X_{211}$ & $\mathrm{Y}_{22}$ & $\mathrm{Y}_{111}$ & $\mathrm{Y}_{112}$ & & $\mathrm{Y}_{211}$ & $\mathrm{Y}_{212}$ & $\mathrm{Y}_{213}$ \\
\hline 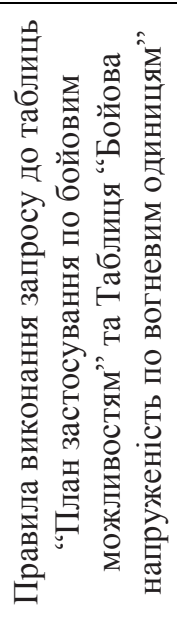 & 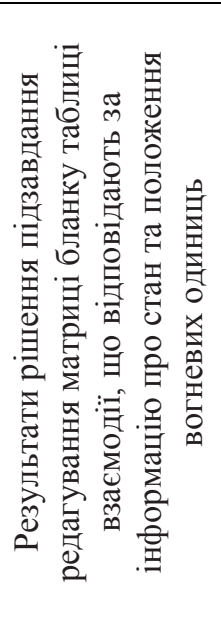 & 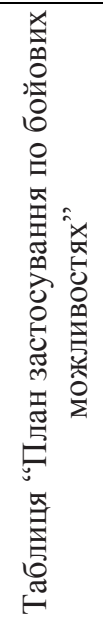 & 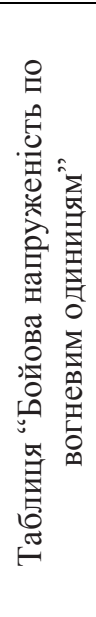 & $Z_{21}=Z_{12}+Z_{\text {cor } 21}+Z_{\text {uzg21 }} \rightarrow \max$ & 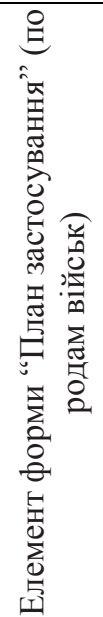 & 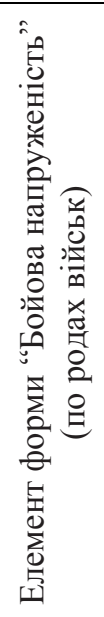 & 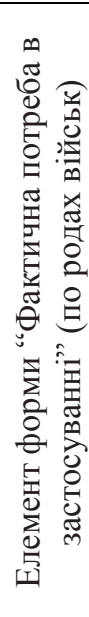 \\
\hline
\end{tabular}

$$
\begin{aligned}
& \mathrm{Z}_{\mathrm{cor} 21}=\mathrm{w}_{3} \mathrm{~K}_{\mathrm{da} 3}^{1}\left(\mathrm{w}_{7} \mathrm{~K}_{\mathrm{q} 11}^{1}+\mathrm{w}_{8} \mathrm{~K}_{\mathrm{q} 12}^{1}\right), \\
& \mathrm{Z}_{\mathrm{uzg} 21}=\mathrm{w}_{9} \mathrm{~K}_{\mathrm{da} 2}^{3}\left(\mathrm{w}_{7} \mathrm{~K}_{\mathrm{q} 11}^{1}+\mathrm{w}_{8} \mathrm{~K}_{\mathrm{q} 12}^{1}\right)
\end{aligned}
$$

де $\mathrm{w}_{7}, \mathrm{w}_{8}, \mathrm{w}_{9}$ вагові коефіцієнти значущості показників $\mathrm{K}_{\mathrm{q} 11}^{1}, \mathrm{~K}_{\mathrm{q} 12}^{1}, \mathrm{~K}_{\mathrm{da} 2}^{3}$.

Параметри задачі формування форми користувача представлені в табл. 3.

Метою формування елемента форми "План застосування" (по родах військ) $\left(\mathrm{Y}_{211}\right) €$ :

відображення результатів запиту $\left(\mathrm{X}_{211}\right)$ до всіх записів таблиці $\mathrm{Y}_{111}$ бази даних ТВ певного роду військ і напрямки його застосування;

реалізація технологічних операцій перегляду плану застосування i вибору необхідного для редагування способу взаємодії.

Метою формування елемента форми "Бойова напруженість" (за родами військ) ( $\left.\mathrm{Y}_{212}\right)$ є:

відображення результатів виконання запиту $\left(\mathrm{X}_{211}\right)$ до бази даних "Бойова напруженість" 3 умовою збігу роду військ таблиці $\mathrm{Y}_{112}$; відображення результатів рішення підзадачі редагування елементів сітки ТВ, які відповідають за інформацію про решту цілей для розміщення в сітку TB;

реалізація технологічних операцій виділення рядка навантаження, обраної для розміщення або редагування в сітці ТВ; перегляд бойового навантаження обраної вогневої одиниці, яку потрібно розмістити в сітці ТВ.

Метою формування елемента форми “Фактична потреба в застосуванні” (по родах військ) ( $\mathrm{Y}_{213}$ ) $\epsilon$ :

відображення результатів рішення задачі редагування елементів сітки ТВ, які відповідають за інформацію про можливості вогневих одиниць, фактично розміщених в сітці ТВ;

реалізація технологічної операцій перегляду навантаження обраної вогневої одиниці, яка фактично розміщена в сітці ТВ.

Задача $\mathrm{E}_{22}$ полягає безпосередньо в редагуванні елементів сітки ТВ, які відповідають за інформацію про вогневі засоби і простір їх застосування.

Математична формалізація даної задачі (4) може бути записана в наступному вигляді: 


$$
\mathrm{f}_{22}\left(\mathrm{X}_{22}, \mathrm{Y}_{22}, \mathrm{Z}_{22}\right) \rightarrow \text { extr }
$$

де $\mathrm{X}_{22}=\left\{\mathrm{Y}_{12}, \mathrm{Y}_{211}, \mathrm{Y}_{212}, \mathrm{Y}_{32}, \mathrm{X}_{221}, \mathrm{X}_{222}\right\}$ множина елементів вектора вхідної інформації задачі $\mathrm{E}_{22}$;

$$
\mathrm{Y}_{22}=\left\{\mathrm{Y}_{221}, \mathrm{Y}_{222}\right\} \quad \text { вихідна інформація }
$$

задачі $\mathrm{E}_{22}$;

$Z_{22}$ комплексний критерій оптимальності задачі $\mathrm{E}_{22}$, що перебуває в максимізації:

суми зважених складових показників коректності $Z_{\text {cor22 }}$ та узгодженості $Z_{\text {uzg22 }}{ }^{3}$ точки зору використання, обробки та візуального відображення вихідної і поточної інформації на всіх аркушах матриці ТВ ( $\left.\mathrm{K}_{\mathrm{q} 11}^{1}, \mathrm{~K}_{\mathrm{q} 12}^{1}, \mathrm{~K}_{\mathrm{q} 13}^{1}\right)$ :

$\mathrm{Z}_{\mathrm{cor} 22}=\mathrm{w}_{3} \mathrm{~K}_{\mathrm{da} 3}^{1}\left(\mathrm{w}_{7} \mathrm{~K}_{\mathrm{q} 11}^{1}+\mathrm{w}_{8} \mathrm{~K}_{\mathrm{q} 12}^{1}+\mathrm{w}_{10} \mathrm{~K}_{\mathrm{q} 13}^{1}\right)$, (14)

$\mathrm{Z}_{\mathrm{uzg} 22}=\mathrm{w}_{9} \mathrm{~K}_{\mathrm{da} 2}^{3}\left(\mathrm{w}_{7} \mathrm{~K}_{\mathrm{q} 11}^{1}+\mathrm{w}_{8} \mathrm{~K}_{\mathrm{q} 12}^{1}+\mathrm{w}_{10} \mathrm{~K}_{\mathrm{q} 13}^{1}\right)$

де $\mathrm{w}_{10}, \mathrm{w}_{11}$ вагові коефіцієнти значущості

відповідно показників $\mathrm{K}_{\mathrm{q} 13}^{1}, \mathrm{~K}_{\mathrm{q} 2}^{1}$;

суми зважених складових показника

максимальної інформаційної повноти $\mathrm{K}_{\mathrm{da} 2}^{1}$;

якості послідовності розміщення інформації про завдання в матриці ТВ ( $\left.\mathrm{K}_{\mathrm{q} 2}^{1}\right)$.

Параметри задачі редагування матриці бланка ТВ, які визначають інформацію про стан і положення вогневих одиниць, представлені в табл. 4.

Алгоритм реалізації задачі $\mathrm{E}_{22}$ наступний:

1. Згідно з інформацією, розміщеною в елементах форми користувача ( $\mathrm{Y}_{211}$ i $\left.\mathrm{Y}_{212}\right)$ про кількість вогневих засобів, які необхідно розподілити за задачами в сітці ТВ ( $\left.\mathrm{Y}_{12}\right)$, виконується редагування елементів поточного листа з метою формування ТВ за обраним на даному етапі бойових дій порядком взаємодії $\left(\mathrm{X}_{221}\right)$.

2. Коректність виконуваних на даному етапі операцій підтримується шляхом програмної реалізації системи контрольних перевірок умов можливості додавання в сітку ТВ певної кількості вогневих одиниць для даної бойової задачі, а також кількості повітряних цілей ( $\left.\mathrm{Y}_{222}\right)$, а саме:

відсутності збігу номера вогневої одиниці, яка призначена на певну повітряну ціль і розташовується в певному просторі, $з$ інформацією, що зберігається в елементах ТВ, що відповідають цій же повітряній цілі в сітках інших листів ТВ (простору виконання бойового завдання);

відсутності збігу положення групи вогневих одиниць, розташованої у відповідному просторі, що виділяється користувачем для виконання бойової задачі, i просторі, забороненому для виконання бойових задач даної групи вогневих одиниць (роду військ) ( $\left.\mathrm{Y}_{212}\right)$;

відповідності кількості вогневих одиниць, які розподіляються на певну кількість повітряних цілей в сітці ТВ поточного листа, кількості

вогневих одиниць, яке виставляється в сітку ТВ на даному етапі ведення бойових дій;

відсутності збігу номера повітряної цілі, яка розподілена на вогневу одиницю, у певному просторі ведення бойових дій, який визначений способом взаємодії, номеру повітряної цілі на інших аркушах ТВ (іншому просторі ведення бойових дій).

Реалізація етапу 3 аналізу якості ТВ вогневих одиниць $\left(\mathrm{E}_{3}\right)$ передбачає вирішення двох задач $\mathrm{E}_{31}$ i $\mathrm{E}_{32}$ (рис. 4).

Метою рішення задачі $\mathrm{E}_{31} \epsilon$ реалізація довідкової та контролюючої функції автоматизованої системи, що полягає в формуванні на окремому аркуші (аркушах) звітної інформації про фактичне навантаження за удар повітряного противника і етап ведення бойових дій, вогневих одиниць і військових частин в цілому, а також формуванні карток ТВ за певний вогневий засіб відповідно до запитів користувача за формою подання та змісту звіту.

Математична формалізація даної задачі (5) може бути записана в наступному вигляді:

$$
\mathrm{f}_{31}\left(\mathrm{X}_{31}, \mathrm{Y}_{31}, \mathrm{Z}_{31}\right) \rightarrow \mathrm{extr}
$$

де $\mathrm{X}_{31}=\left\{\mathrm{X}_{311}, \mathrm{Y}_{22}\right\} \quad$ множина елементів вектора вхідної інформації задачі $\mathrm{E}_{31}$;

$$
\mathrm{Y}_{31}=\left\{\mathrm{Y}_{311}, \mathrm{Y}_{312}, \mathrm{Y}_{313}, \mathrm{Y}_{314}\right\} \quad \text { вихідна }
$$
інформація задачі $\mathrm{E}_{31}$;

$\mathrm{Z}_{31}$ комплексний критерій оптимальності задачі $\mathrm{E}_{31}$, який реалізує етап формування ТВ, що перебуває в максимізації якості формованої системи звітності, а точніше суми його зважених компонент: інформаційної повноти $\left(\mathrm{K}_{\mathrm{da} 2}^{1}\right)$; коректності $\left(\mathrm{K}_{\mathrm{da} 3}^{1}\right)$, актуальності $\left(\mathrm{K}_{\mathrm{da} 1}^{3}\right)$; настроюваності ( $\mathrm{K}_{\mathrm{da3}}^{3}$ ) та якості звітності ( $\left.\mathrm{K}_{\mathrm{q} 3}^{1}\right)$, де $\mathrm{w}_{12}, \mathrm{w}_{13}, \mathrm{w}_{14}$ вагові коефіцієнти значущості відповідно показників $\mathrm{K}_{\mathrm{da} 1}^{3}, \mathrm{~K}_{\mathrm{da} 3}^{3}, \mathrm{~K}_{\mathrm{q} 3}^{1}$.

Параметри задачі формування звітної інформації про фактичне бойове напруження вогневих одиниць та військових частин в цілому представлені в табл. 5.

Рішення задачі $\mathrm{E}_{32}$ передбачає оцінку якості формованої ТВ здійснювати за допомогою зіставлення можливостей вогневих одиниць i характеристик повітряних цілей на кожному етапі 
Таблиця 4 Параметри задачі редагування матриці бланку ТВ ( $\mathrm{E}_{22}$ )

\begin{tabular}{|c|c|c|c|c|c|c|c|c|}
\hline \multicolumn{6}{|c|}{ Вхідна інформація $\mathrm{X}_{22}$} & \multirow[t]{2}{*}{ Локальний критерій оптимальності $Z_{22}$} & \multicolumn{2}{|c|}{$\begin{array}{c}\text { Вихідна } \\
\text { інформація } \\
\text { Y }_{22}\end{array}$} \\
\hline$X_{221}$ & $X_{222}$ & $Y_{12}$ & $\mathrm{Y}_{211}$ & $\mathrm{Y}_{212}$ & $Y_{32}$ & & $\mathrm{Y}_{221}$ & $Y_{222}$ \\
\hline 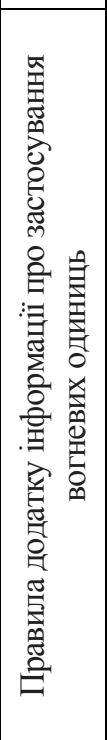 & 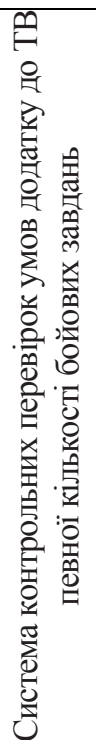 & 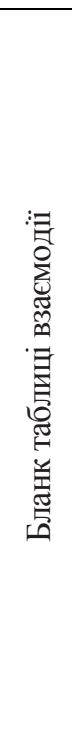 & 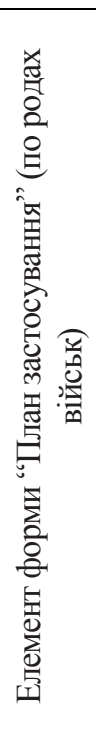 & 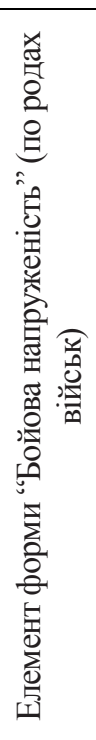 & 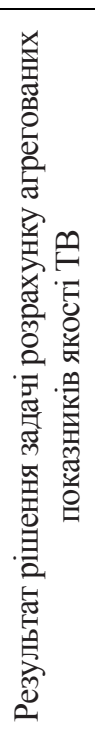 & $\mathrm{Z}_{22}=\mathrm{Z}_{12}+\mathrm{Z}_{\mathrm{cor} 22}+\mathrm{Z}_{\mathrm{uzg} 22}+\mathrm{w}_{11} \mathrm{~K}_{\mathrm{q} 2}^{1} \rightarrow \max$ & 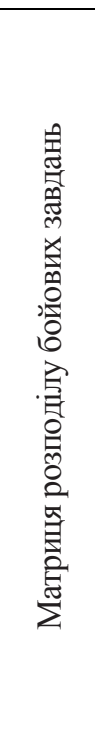 & 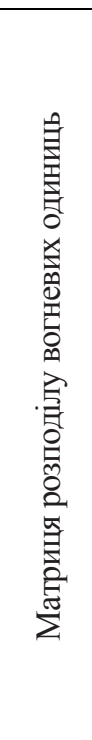 \\
\hline
\end{tabular}

Таблиця 5 Параметри задачі формування звітної інформації ( $\left.\mathrm{E}_{31}\right)$

\begin{tabular}{|c|c|c|c|c|c|c|c|}
\hline \multicolumn{3}{|c|}{$\begin{array}{c}\text { Вхідна } \\
\text { інформація } \mathrm{X}_{31}\end{array}$} & \multirow{2}{*}{ Локальний критерій оптимальності $Z_{31}$} & \multicolumn{4}{|c|}{ Вихідна інформація $\mathrm{Y}_{31}$} \\
\hline $\mathrm{X}_{311}$ & $\mathrm{Y}_{221}$ & $\mathrm{Y}_{222}$ & & $\mathrm{Y}_{311}$ & $\mathrm{Y}_{312}$ & $\mathrm{Y}_{313}$ & $\mathrm{Y}_{314}$ \\
\hline 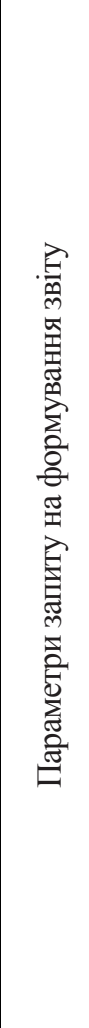 & 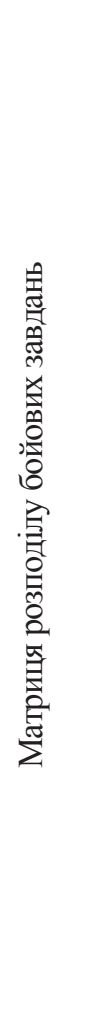 & 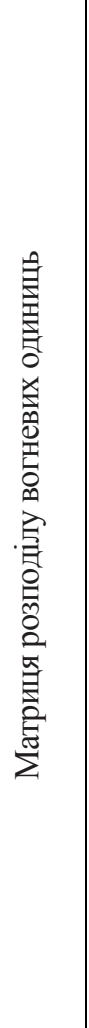 & $\mathrm{Z}_{31}=\mathrm{w}_{2} \mathrm{~K}_{\mathrm{da} 2}^{1}+\mathrm{w}_{3} \mathrm{~K}_{\mathrm{da} 3}^{1}+\mathrm{w}_{12} \mathrm{~K}_{\mathrm{da} 1}^{3}+\mathrm{w}_{13} \mathrm{~K}_{\mathrm{da} 3}^{3}+\mathrm{w}_{14} \mathrm{~K}_{\mathrm{q} 3}^{1} \rightarrow \max$ & 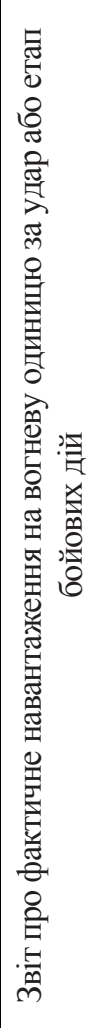 & 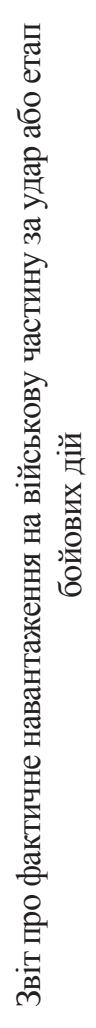 & 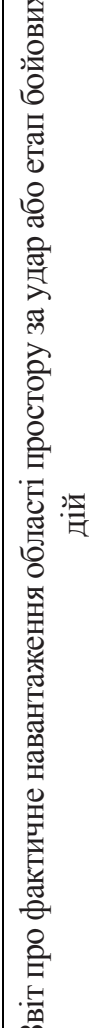 & 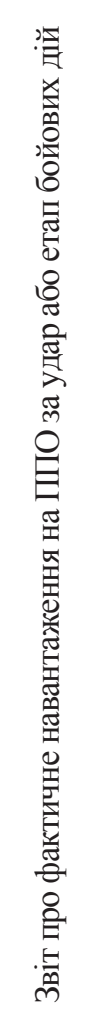 \\
\hline
\end{tabular}


бойових дій і по кожному удару з урахуванням наступних показників раціональності:

1. Рівня небезпеки знищення повітряної цілі $\left(\mathrm{Z}_{\mathrm{PC}}\right)$ :

$$
\mathrm{Z}_{\mathrm{PC}}=\mathrm{b}_{1} \mathrm{~L}_{1}+\mathrm{b}_{2} \mathrm{~L}_{2}+\mathrm{b}_{3} \mathrm{~L}_{3}
$$

де $\mathrm{L}_{1}$ кількість типів вогневих одиниць ППО, які можуть знищити даний тип повітряної цілі;

$\mathrm{L}_{2}$ середня ступінь загрози від даного типу повітряної цілі;

$\mathrm{L}_{3}$ ступінь присутності в ТВ логічної послідовності розподілу вогневих одиниць в просторі, а також чергування різних способів взаємодії в межах зони ведення бойових дій;

$\mathrm{b}_{1}, \mathrm{~b}_{2}, \mathrm{~b}_{3}$ вагові коефіцієнти значущості відповідно показників $\mathrm{L}_{1}, \mathrm{~L}_{2}, \mathrm{~L}_{3}$;

2. Рівня бойових можливостей вогневих одиниць $з$ урахуванням впливу спільних (в одній зоні) бойових дій $\left(\mathrm{Z}_{\mathrm{vo}}\right)$.

Математична формалізація даного завдання (6) може бути записана в наступному вигляді:

$$
\begin{gathered}
\mathrm{f}_{32}\left(\mathrm{X}_{32}, \mathrm{Y}_{32}, \mathrm{Z}_{32}\right) \rightarrow \text { extr } \\
\text { де } \mathrm{X}_{32}=\left\{\mathrm{X}_{321}, \mathrm{X}_{322}, \mathrm{X}_{323}, \mathrm{X}_{324}, \mathrm{Y}_{22}\right\}
\end{gathered}
$$

множина елементів вектора вхідної інформації задачі $\mathrm{E}_{32}$;

$$
\mathrm{Y}_{32}=\left\{\mathrm{Y}_{321}, \mathrm{Y}_{322}, \mathrm{Y}_{323}, \mathrm{Y}_{324}\right\} \quad \text { вихідна }
$$

інформація задачі $\mathrm{E}_{32}$;
$\mathrm{Z}_{32}$ комплексний критерій оптимальності задачі $E_{32}$, який перебуває в оптимізації критерію рівномірності завантаження вогневих одиниць.

Оскільки приватні критерії (Таблиця 1 6), які використовуються при вирішенні множини задач $\mathrm{E}=\left\{\mathrm{E}_{11}, \mathrm{E}_{12}, \mathrm{E}_{21}, \mathrm{E}_{22}, \mathrm{E}_{31}, \mathrm{E}_{32}\right\} \in$ результатами декомпозиції загальної задачі на множина локальних об'єктів автоматизації процесу формування ТВ, то їх оптимізація забезпечує досягнення екстремуму головного критерію задачі автоматизації формування ТВ $Z_{\mathrm{ATB}}$ :

максимальний ступінь автоматизації формування $\mathrm{TB} \mathrm{Z}_{\mathrm{da}}$;

максимальна якість формування $\mathrm{TB} \mathrm{Z}_{\mathrm{q}}$.

$$
\mathrm{Z}_{\mathrm{ATB}}=\mathrm{v}_{1} \mathrm{Z}_{\mathrm{da}}+\mathrm{v}_{2} \mathrm{Z}_{\mathrm{q}} \rightarrow \max
$$

де $v_{1}$ i $v_{2}$ вагові коефіцієнти значущості відповідно показників $\mathrm{Z}_{\mathrm{da}}$ i $\mathrm{Z}_{\mathrm{q}}$.

Далі, після реалізації основних етапів автоматизації відбувається доопрацювання сформованої ТВ 3 метою максимального врахування факторів і узгодження суперечливих критеріїв, а саме: врахування замислу командира

\begin{tabular}{|c|c|c|c|c|c|c|c|}
\hline \multicolumn{3}{|c|}{$\begin{array}{c}\text { Вхідна інформація } \\
\mathrm{X}_{32}\end{array}$} & \multirow[t]{2}{*}{ Локальний критерій оптимальності $Z_{32}$} & \multicolumn{4}{|c|}{ Вихідна інформація $\mathrm{Y}_{32}$} \\
\hline $\mathrm{X}_{321}$ & $\mathrm{Y}_{221}$ & $\mathrm{Y}_{222}$ & & $\mathrm{Y}_{321}$ & $\mathrm{Y}_{322}$ & $Y_{323}$ & $\mathrm{Y}_{324}$ \\
\hline 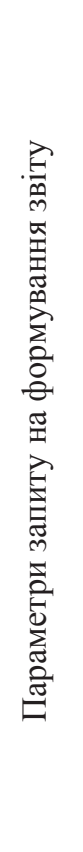 & 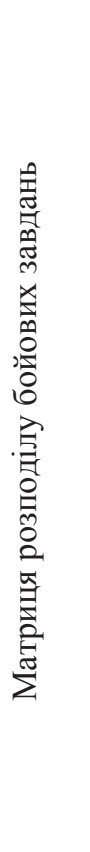 & 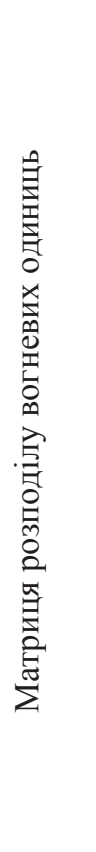 & $\mathrm{Z}_{32}=\mathrm{w}_{7} \mathrm{~K}_{\mathrm{q} 11}^{2}+\mathrm{w}_{8} \mathrm{~K}_{\mathrm{q} 12}^{2}+\mathrm{w}_{14} \mathrm{~K}_{\mathrm{q} 2}^{2} \rightarrow \mathrm{opt}$ & 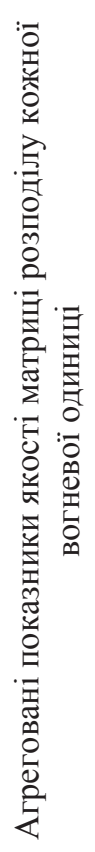 & 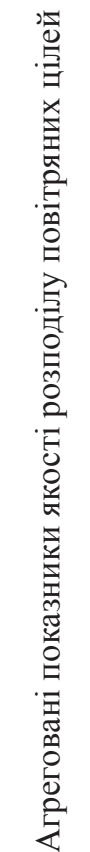 & 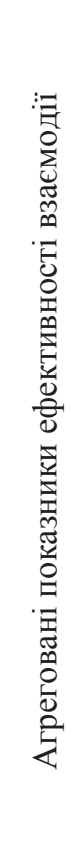 & 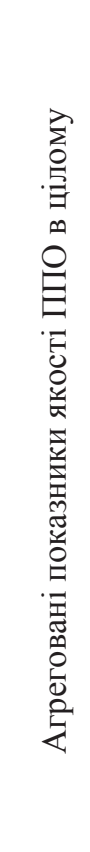 \\
\hline
\end{tabular}
або обмежень щодо здійснення взаємодії сил і засобів; врахування особливостей організації протиповітряної оборони тощо.

Таблиця 6 Параметри задачі формування звітної інформації ( $\mathrm{E}_{32}$ ) 
Висновки й перспективи подальших досліджень. Таким чином, запропонована методика із застосуванням методів декомпозиції багатокритеріальної задачі формування таблиці взаємодії зенітних ракетних військ 3 винищувальною авіацією дозволяє:

1. За рахунок застосування принципів системного підходу врахувати критерії оптимальності та обмеження двох взаємопов'язаних задач: задачі оптимізації основних показників таблиці взаємодії зенітних ракетних військ з авіацією і задачі її формування;

2. За рахунок проведення декомпозиції складного завдання спростити рішення багатокритеріальної задачі шляхом формування ієрархічної структури критеріально-узгоджених задач “припустимої” складності;

\title{
Лimepamypa
}

\section{1. Довідник}

3 (А.Я.Торопчин, І.О.Романенко, Ю.Г.Даник та ін. Харків: Вид. “Харків”., 2003. 366 с. 2. Теория расписаний. Задачи и алгоритмы: учебное пособие/А.А.Лазарев, Е.Р.Гафиров. М.: Вид. НГУ ім. М.В.Ломоносова., 2011. 222 с. 3. Задачи календарного планирования и методы их рещения./В.В.Шкурба, Т.П.Подчасова, А.Н.Пшичук, Л.П.Тур. Київ.: Наукова думка, 1996. 154 с. 4. Введение в теорію расписаний./В.С.Токаев, В.В.Шкурба. М.: Наука., 1975. 340 с. 5. Аничкин А.С. Современные модели и методы теории расписаний./А.С.Аничкин, В.А.Семенов//Труды ИСП РАН. - 2014. том 26 вып. 2. С. 5-50. 6. Мельников А.Ю., Сусяк Н.М. Автоматизированное составление расписания занятий в высшем учебном заведении./ А.Ю.Мельников, Н.М.Сусяк//Современные проблемы информатизации в информационных системах и телекомуникациях: Сб. трудов. Вып. 11 Воронеж.: Вид. "Научная книга", 2006. С. 344345 .
3. За рахунок методики формування таблиці взаємодії зенітних ракетних військ 3 авіацією знизити трудомісткість виконання ручних операцій по іiі формуванню, впровадити ефективну систему контролю помилок i логічних невідповідностей в отриманій таблиці взаємодії, максимально врахувати особливості, основні цілі та завдання формування таблиці взаємодії зенітних ракетних військ з авіацією в конкретних умовах бойових дій (операціi);

4. За рахунок методики оцінки якості таблиці взаємодії, що сформована 3 урахуванням бойових можливостей вогневих засобів зенітних ракетних військ та авіації, а також рівня складності поставлених задач досягти рівномірності завантаження вогневих засобів зенітних ракетних військ і авіації для повної реалізації їх бойових можливостей.

7. Ризун Н.О. Применение методов декомпозиции при решении многокритериальной задачи автоматизации составления расписания учебных занятий в ВУЗе./ Н.О. Ризун// Восточно-европейский журнал передовых технологий. Вип. 2(44) - Харків: 2010. - С. 59-70. 8. Рєзнік Д.В. Використання генетичного алгоритму для вирішення завдання планування взаємодії./Д.В Рєзнік// Сучасні інформаційні технології у сфері безпеки та оборони. Вип. 3(24) - Київ: Вид. НУОУ ім..Івана Ченрняховського, 2015. - С. 97-102. 9. Ткач І.М., Мірненко B.I., Деменєв О.М. Методика вибору економічно доцільного технологічного процесу виробництва при проектуванні складних технічних об'єктів/ I.М. Ткач, В.I. Мірненко, О.М. Деменєв// Менеджмент: Збірник наукових праць Міжгалузевої академії управління. Вип. 16 - Київ: Вид. Міжгалузевий інститут управління, 2013. - С. 147-170.

\section{МЕТОДИКА ФОРМИРОВАНИЯ ТАБЛИЦЫ ВЗАИМОДЕЙСТВИЯ}

\author{
Дмитрий Викторович Резник (канд. воен. наук) \\ Михаил Антонович Левченко (канд. воен. наук, доцент) \\ Олег Андреевич Заболотный (канд. воен. наук, доцент) \\ Василий Семенович Мельниченко (канд. воен. наук, доцент)
}

\section{Национальный университет обороны Украины имени Ивана Черняховского, Киев, Украина}

Поиск новых подходов и разработка на их основе инструментов поддержки принятия решения командующего (командира) на организацию взаимодействия сил и средств в ходе ведения современных боевых действий со скоротечностью изменения обстановки, в последнее время стало предметом интенсивных научных исследований. Одним из перспективных направлений таких исследований является разработка специальных автоматизированных систем, которые используются для формирования таблицы взаимодействия сил и средств во время совместного выполнения ними оперативных (боевых) задач. Исследования в области разработки таких систем привели к появлению (предъявлению) новых требований к формированию таблицы взаимодействия. Во-первых, таблица должна учитывать не только достоверные данные о текущей оперативно-тактической обстановке, но и данные по ее изменению в режиме времени, близкому к реальному. Во-вторых, автоматизированная система в прочессе формирования таблицы взаимодействия должна иметь и использовать базу знаний о ее организации, которая постоянно обновляется на основании предыдущего опыта ведения операций (боевых действий). В статье описывается один из подходов автоматизированного формирования 
таблицы взаимодействия зенитных ракетных войск с истребительной авиацией, который основан на применении метода декомпозиции многокритериальной задачи.

Ключевые слова: таблиц̧а взаимодействия; декомпозицุия; автоматизация формирования; многокритериальная задача, противовоздушная оборона.

\title{
METHODS OF THE INTERACTION SCHEDULE'S CREATION
}

\author{
Dmytro V. Rieznik (Candidate of Military Sciences) \\ Mykhailo A. Levchenko (Candidate of Military Sciences, Associate Professor) \\ Oleh A. Zabolotnyi (Candidate of Military Sciences, Associate Professor) \\ Vasyl S. Melnychenko (Candidate of Military Sciences, Associate Professor)
}

\section{National Defence University of Ukraine named after Ivan Cherniakhovsky, Kyiv, Ukraine}

Lately the search of the ways to create tools and approaches for taking a commander's decision related to the organization of the forces' interaction during the changing military actions has become a subject of the multiple scientific researches. One of the promising branches of these studies is creation of the special automized systems that form the schedules of interactions to support the commander's decision in the fastchanging military environment. These systems research has determined the necessity of taking into account both the conditions of the current military situation and the past experience of the forces' interaction organization. This article describes one of the approaches to the creation of multiple-criteria schedule of anti-aircraft missile forces and fighter aviation's interaction. The approach is based on the decomposition of multiple-criteria problem. Also the article provides recommendations to the anti-aircraft missile forces and fighter aviation's interaction during the air defense operation schedule's creation automation.

Key words: interaction schedule; decomposition; automation of the creation; multiple-criteria problem; air defense.

\section{References}

1. Dovidnyk z protypovitryanoyi oborony. / A.YA.Toropchin, I.O.Romanenko, YU.H.Danik $i$ in. - Kharkiv: Vyd. "Kharkiv"., 2003. - 366 ps. 2. Teoriya rozkladiv. Zavdannya $i$ alhorytmy: navchal nyy posibnyk / A.A.Lazarev, E.R.Hafirov. - M.: Yzd. NHU im. M.V.Lomonosova., 2011. 222 p. 3. Zavdannya kalendarnoho planuvannya $i$ metody yikh reshcheniya. / V.V.Shkurba, T.P.Podchasova, A.N.Pshichuk, L.P.Tur. - Kyyiv.: Naukova dumka, 1996. 154 s. 4. Vvedennya v teoriyu rozkladiv. / V.S.Tokaev, V.V.Shkurba. - M.: Nauka., 1975. - 340 p. 5. Anichkin A.S. Suchasni modeli i metody teoriyi rozkladiv. / A.S.Anichkin, V.A.Semenov // Pratsi ISP RAN. - 2014.-tom 26 vyp. 2. - P. 5-50. 6. Mel nykov A.U., Susyak N.M. Avtomatyzovane skladannya rozkladu zanyat $u$ vyshchomu navchal nomu zakladi. / A.U.Mel nikov, N.M.Susyak // Suchasni problemy informatyzatsiyi $v$ informatsiynykh systemakh $i$ telekomunikatsiyi: Zb. prats . Vyp. 11 - Voronezh.: Yzd. "Naukova knyha", 2006. - P. 344-345. 7. Rizun N.A.
Zastosuvannya metodiv dekompozytsiyi pry vyrishenni bahatokryterial noyi zadachi avtomatyzatsiyi skladannya rozkladu navchal nykh zanyat u vyshchomu navchal nоти zakladi. / N.A. Rizun // Skhidnoyevropeys kyy zhurnal peredovykh tekhnolohiy. Vyp. 2 (44) - Kharkiv: 2010. - P. 59-70. 8. Rieznik D.V. Vykorystannya henetychnoho alhorytmu dlya vyrishennya zavdannya planuvannya vzayemodiyi. / D.V Reznyk // Suchasni informatsiyni tekhnolohiyi $v$ sferi bezpeky $i$ oborony. Vyp. 3 (24) - Kyyiv: Vyd. NUOU im..Ivana Chenrnyakhovs koho, 2015 - P. 97-102. 9. Tkach I.M., Mirnenko V.I., Demenev A.N. Metodyka vyboru ekonomichno dotsil noho tekhnolohichnoho protsesu vyrobnytstva pry proektuvanni skladnykh tekhnichnykh ob'yektiv / I.M. Tkach, V. I. Mirnenko, A.N. Demenev // Menedzhment: Zbirnyk naukovykh prats Mizhhaluzevyy akademiyi upravlinnya. Vyp. 16 - Kyyiv: Vyd. Mizhhaluzevyy instytut upravlinnya, 2013. - P. 147-170. 